\title{
STUDY OF AN EVAPORATION SYSTEM FOR SODIUM HYDROXIDE SOLUTION
}

\author{
Md. Atikur Rahman* and Nymul Ehsan Khan \\ Department of Chemical Engineering \\ Bangladesh University of Engineering and Technology, Dhaka 1000, Bangladesh
}

\begin{abstract}
The textile industry in Bangladesh uses a substantial quantity of caustic soda (sodium hydroxide) to clean and prepare fabrics for dyeing. In all textile mills dealing with finishing, particularly with the mercerizing of cotton and mixed cotton fabrics, dilute caustic soda solutions come out as effluent from mercerizing unit. Caustic soda is expensive and its disposal without neutralization is unacceptable. A considerable amount of caustic soda can be saved if the dilute solution leaving the mercerizing step can be collected, concentrated and recycled. The concentration of the dilute caustic soda solution can be carried out by means of evaporation. A single effect evaporation system to concentrate the dilute sodium hydroxide solution was constructed and operated. The operating results confirm the economic viability of such recovery scheme.
\end{abstract}

\section{Introduction}

Evaporation of sodium hydroxide solution is performed on large scale and over a wide concentration range in the production of sodium hydroxide. The textile dyeing and finishing industry in Bangladesh use dilute solution of caustic soda in different operating steps such as desizing, washing and mercerizing. The concentrations of aqueous caustic soda vary from 4 to $20 \%$ by weight. At the end of such operations, the caustic solutions are discarded as effluents having lower caustic concentration, which pollutes the water body. The concentration of caustic solution leaving the mercerizing section as effluent is about $4 \%$ by weight. A laboratory scale setup capable of producing $25 \mathrm{~kg} / \mathrm{hr}$ water vapor and resulting in a solution of $20 \%$ sodium hydroxide from a $4 \%$ by weight of caustic soda effluent was designed, built and tested.

This paper deals with the operation of the laboratory scale evaporation setup and its application in the industry for recovering caustic soda from waste effluent.

\section{Experimental Study}

A $0.381 \mathrm{~m}$ ID and $2.44 \mathrm{~m}$ long cylindrical column with conical bottom made from $6.35 \mathrm{~mm}$ SS 304 Sheet was used as the flash separator for the boiling solution. A shell and tube exchanger (6 tubes $-1.52 \mathrm{~m}$ long, 9.14 $\mathrm{mm}$ ID, SS 304, $0.10 \mathrm{~m}$ ID CS Shell) was used for vaporization and a preheater of shell and tube type (4 tubes - $0.76 \mathrm{~m}$ long, $9.14 \mathrm{~mm}$ ID, SS 304, $0.076 \mathrm{~m}$ ID CS shell) was used to preheat the feed solution with vapor from the vapor separator. The steam used in the exchanger was at 16-20 psig. The setup is shown in Figure 1. Details of the setup are available elsewhere ${ }^{1}$.
The system was designed to evaporate of $25 \mathrm{~kg} / \mathrm{hr}$ of water from $31.25 \mathrm{~kg} \mathrm{4 \%}$ feed solution of sodium hydroxide to yield $6.25 \mathrm{~kg} 20 \%$ solution. The flash tank would constantly contain $40 \mathrm{~kg}$ of $20 \%$ solution. The dilute feed solution, after passing through the preheater, would mix with a circulating stream of concentrated solution from the tank and pass through the evaporator. The mixture of liquid and vapor enters the flash tank where the vapor separates from the liquid and leaves through the top of the flash tank to pass through the preheater to preheat the feed solution. The flow was under natural circulation. The operability of the system was tested by using water as the working fluid.

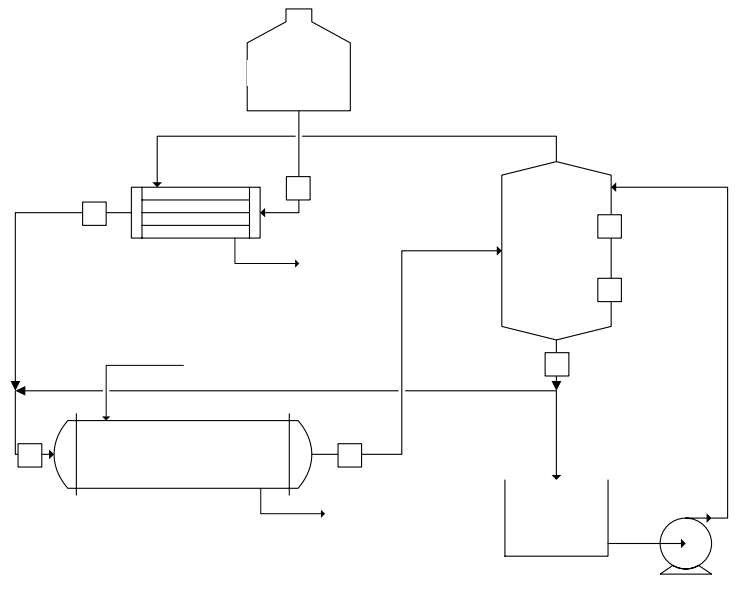

Fig. 1: Setup of the process Results and Discussions

After testing, the setup was run using actual solution of sodium hydroxide. Table 1 lists the data collected and calculated results in a summarized form. The feed rate was calculated using initial and final feed tank readings and intermediate charges. The difference in 
flash tank levels (between initial and final) and the amount of solution fed was used to calculate the total water evaporated and the average evaporation rate. Table 2 gives a calculation of the cost savings for a typical textile factory producing $1000 \mathrm{~kg}$ of dilute depreciation neither does it include the cost saved for solution leaving mercerizing unit per day (this costs do not include the cost of electricity, overhead and waste treatment that would have been required). As can be seen a textile factory involved in dyeing and finishing could save around Tk. 1000 for each $1000 \mathrm{~kg}$ of mercerizing effluent.

Table: 1: Data Collected and Calculated Results

\begin{tabular}{|c|c|c|c|c|c|c|c|c|c|c|c|c|}
\hline \multirow[b]{2}{*}{ Run } & \multirow[b]{2}{*}{$\begin{array}{c}\text { Steam } \\
\text { Press., } \\
\text { psig }\end{array}$} & \multirow[b]{2}{*}{$\begin{array}{c}\text { Run } \\
\text { Time, } \\
\text { hr }\end{array}$} & \multirow[b]{2}{*}{$\begin{array}{l}\text { Feed } \\
\text { Rate, } \\
\text { kg/hr }\end{array}$} & \multirow[b]{2}{*}{$\begin{array}{l}\text { Water } \\
\text { Evap. } \\
\text { Rate, } \\
\text { kg/hr }\end{array}$} & \multicolumn{3}{|c|}{ Evaporator } & \multicolumn{3}{|c|}{ Preheater } & \multirow[b]{2}{*}{$\begin{array}{c}\text { Water } \\
\text { evap/sq. ft } \\
\text { heat } \\
\text { transfer } \\
\text { surface }\end{array}$} & \multirow[b]{2}{*}{$\begin{array}{c}\text { Ratio of } \\
\text { water evap } \\
\text { to steam } \\
\text { consumed }\end{array}$} \\
\hline & & & & & $\begin{array}{c}\text { Total } \\
\text { Steam } \\
\text { Cond., } \\
\text { kg }\end{array}$ & $\begin{array}{l}\text { Cond. } \\
\text { Rate, } \\
\text { kg/hr }\end{array}$ & $\begin{array}{l}\text { Overall Heat } \\
\text { Transfer } \\
\text { Coeff., } \\
\text { W/m².K }\end{array}$ & $\begin{array}{l}\text { Steam } \\
\text { Cond, } \\
\text { kg/hr }\end{array}$ & $\begin{array}{l}\text { Cond. } \\
\text { Rate, } \\
\text { kg/hr }\end{array}$ & $\begin{array}{l}\text { Overall Heat } \\
\text { Transfer } \\
\text { Coeff., } \\
\text { W/m².K }\end{array}$ & & \\
\hline $1+2$ & 20 & $4.5+1$ & 296 & 22 & 145.7 & 26.5 & $\begin{array}{c}2195- \\
2425 \\
\end{array}$ & 24.65 & 5.5 & 362 & 5.99 & 0.83 \\
\hline $3+4$ & 20 & $\begin{array}{c}2+3 \text {, for } \\
\text { flow } \\
1.67+3\end{array}$ & 24 & 18.76 & 126.3 & 25.3 & $\begin{array}{l}1875- \\
2072\end{array}$ & 17.9 & 3.85 & 319 & 5.11 & 0.74 \\
\hline
\end{tabular}

Heat transfer calculation and data ${ }^{2,4}$.

Table 2: Cost calculation for a typical textile factory.

\begin{tabular}{|c|c|c|}
\hline & Quantity & Cost. Tk \\
\hline Feed solution $(4 \%)$ & $1000 \mathrm{~kg}$ & \\
\hline Sodium hydroxide saved & $40 \mathrm{~kg}$ & \\
\hline Market price of sodium hydroxide & $\mathrm{Tk} 40 / \mathrm{kg}$ & \\
\hline Cost of sodium hydroxide saved & & 1600 \\
\hline Water evaporated & $800 \mathrm{~kg}$ & \\
\hline Steam consumed (taking water evaporated to steam consumed ratio $=0.8$ ) & $1000 \mathrm{~kg}$ & \\
\hline Heat required & $2.257 \times 10^{6} \mathrm{~kJ}$ & \\
\hline Heat provided by NG (taking boiler efficiency $=0.8$ ) & $2.821 \times 10^{6} \mathrm{~kJ}$ & \\
\hline Heating value of NG (source www titasgas org bd) & $1050 \mathrm{Btu} / \mathrm{SCF}(1108 \mathrm{~kJ} / \mathrm{SCF})$ & \\
\hline NG required & $2546.2 \mathrm{SCF}$ & \\
\hline Price of NG (source www titasgas org bd) & Tk 145.2/1000 SCF & \\
\hline Cost of NG & & 370 \\
\hline Cost of daily labor & & 200 \\
\hline Cost saved & & 1030 \\
\hline
\end{tabular}

\section{Conclusion}

The recovery of caustic soda from the discarded effluent can be performed by using the system used in this work. This recovery would bring economic benefit to the industry and lead to resource recovery and reduction of treatment cost.

\section{Acknowledgement}

The authors are indebted to Dr. AKMA Quader, Professor of Chemical Engineering Department, BUET for his kind supervision of this project

\section{References}

1. Khan, Nymul E. Khan and Rahman, Md. Atikur, Study of an Evaporation System for Sodium Hydroxide Solution, B.Sc. Engg. (Chemical) Thesis, Chem. Eng. Dept., BUET, November 2006.

2. Donald Q. Kern, Process Heat Transfer, Tata McGraw-Hill, New Delhi, 1997.

3. Alan S. Foust, Leonard A. Wenzel, Curtis W. Clump, Louis Maus and L. Bryce Andersen, Principles of Unit Operations (Second Edition), John Wiley \& Sons, 1994.

4. Perry's Chemical Engineers' Handbook (Seventh Edition), Editors: Robert H. Perry (Late), Don W. Green and James O. Malony (Associate Editor), McGraw-Hill, 1997. 